\title{
Class conflicts, defense of rights and Social Work
}

\author{
Conflitos de classes, defesa de direitos e Serviço Social
}

JAime Hillesheim @

Universidade Federal de Santa Catarina, Florianópolis, SC, Brazil.

\author{
8003
}

ABSTRACT - Based on Marxian and Marxist assumptions, in particular, the contributions of György Lukács to law as ideology, we try to elicit reflection on the current theoretical and practical challenges to social service to prevent the profession from seeing its ethico-political project capitulate in view of the intensification of the capital offensive against labor. In this paper, the contradictions of the social worker's work in defending and extending rights vis-a-vis the own logic of bourgeois sociability are discussed. We address the challenges imposed by the limits of such sociability, which require, to be faced, an understanding of critical social theory, given its potential to contribute to professional work in line with the values and principles of the aforementioned project.

Keywords: Class struggle. Rights. Human emancipation. Social work.

RESUMO - A partir de pressupostos marxianos e marxistas, em particular, das contribuições de György Lukács sobre o direito como ideologia, procura-se, aqui, instigar a reflexão sobre os desafios teóricos e práticos do serviço social no tempo presente, para que a profissão não veja seu projeto ético-político capitular em face da intensificação da ofensiva do capital sobre o trabalho. No presente artigo são abordadas, essencialmente, as contradições do trabalho do assistente social na defesa e ampliação dos direitos em face da lógica própria da sociabilidade burguesa. São situados os desafios impostos pelos limites dessa sociabilidade que exigem, para o seu enfrentamento, a compreensão da teoria social crítica, haja vista seu potencial de subsidiar o trabalho profissional em consonância com os valores e princípios contantes do projeto supracitado.

Palavras-chave: Luta de classes. Direitos. Emancipação Humana. Serviço social. 


\section{Introduction}

- he most critical approaches to ideology, notably those in the Marxist theoretical spectrum, are marked by the idea of reality inversion. This inversion, in our opinion, is always oriented to the assuagement of the conflicts arising from class antagonisms. This shows the importance of discussing the functions of the law complex in the development process of the social being, which inscribes it dialectically in the field of ideologies. By means of the efforts of social workers for the creation, defense and extension of social rights, these two complexes communicate with each other when their agents act toward political emancipation.

For social work, in particular, its legitimacy is closely related to its ability to allow the users of the services it operates, individually or collectively, to be reached by the rights agreed upon in the framework of bourgeois sociability. From this point of view, we can say that professional work - with its theoreticalmethodological and ethico-political fundamentals - becomes concrete in the field of social policies, whose forms and contents are determined by class dynamics. The social policies are mediations for workers (users of social services) to gain access to part of the wealth produced by them, as a result of the inequalities produced by the social form ruled by capital, whose dynamics was duly explained by Marx when he developed his theory of value. And due to the antagonisms between capital and labor, this social form cannot dispense with mechanisms that attempt to give legitimacy to the processes that ensure the continued and increasing production of an economic surplus to be appropriated privately by the classes that own the means of production. In this regard, both social work and law, as well as the existing juridical-legal structure, play related roles: they contribute to solve conflicts in the class society.

Our purpose in this article is to problematize, based on the presuppositions of György Lukács (2013), the relation between social work and the law complex and, more specifically, shed light on the discourses about rights assimilated by social workers. We think that this problematization is quite timely, considering the troubled reality experienced by Brazilian workers in the face of the advance of capital on their historic achievements in terms of social rights. Altogether, the various offensives in progress are not only proposals for counter-reforms but, more than that, they intend to usher in a new form of State, buttressed with an even more radical and extreme neoliberal variation, after the failure of the neodevelopmentist proposals based on the conciliation of classes carried out during the labor governments in Brazil (2003-2016). In this new state structure, there is no room for the needs of the working class, for which the formulated responses largely depart from the perspectives of universalization of social rights, treated by the ruling classes as inappropriate privileges that hinder the country's economic growth.

With the advent of the parliamentary, judicial and media coup in 2016 and with the rise of the ultraconservative political forces represented by President Jair Bolsonaro, workers have faced, although without being aware of the ongoing offensive, harsh attacks on the set of rights achieved by means of historic political struggles. The program embraced by the crooked government of Michel Temer at the time indicated that he was aware of the conditions imposed by the national bourgeoisie for his provisional stay in power. As a result, he put a project into practice that quickly and primarily allowed: the creation and strengthening of strategies for the use of the economic surplus appropriated by the State in favor of capital, the strengthening of actions aimed at taming the working classes, and the establishment of a pattern of objective conditions to expand the super-exploitation processes that were presented as the only alternative to all workers. All of this was aggravated by the political polarization that divided the country after the 2016 coup and culminated in the electoral results of 2018 , which endorsed the continuity and intensification of the processes of suppression of the rights achieved by Brazilian society, especially in the periods that followed the so-called redemocratization.

This reality requires that social work, in the context of the struggle for rights, overcomes endogenous professional responses, so that these struggles can articulate with the struggle for the creation of objective and subjective conditions to overcome the capitalist order. This is not a question of abstracting the constraints that the profession encounters in the labor market, but of making the struggle for rights a tactic that is not dissociated from the strategy of building another sociability. Without having this necessary articulation on the horizon, the Brazilian social work tends to capitulate in the context of a conciliation policy updated by 
the elite - a policy that has been historically adopted in Brazil in the face of economic and political crises - and to assimilate the proposed transformism and/or setbacks, building performance parameters limited to the possibilities of reality.

In this article, we will try to bring some theoretical reflections on the law complex according to Lukacsian formulations and to problematize issues that are posed to social work in view of the ethical and political commitment that this has assumed in the defense of the maintenance and expansion of social rights in the context of a class society.

\section{The ideological role of the law complex in a class society}

Taking as a presupposition the thesis supported by Marx whereby he claims that a politico-ideological superstructure arises from the economic basis, György Lukács (2013) - a prominent Hungarian philosopher on the Marxist intellectual scene of the 20th century - warns that it is wrong to understand ideology as a representation of the thinking of singular individuals. According to the author:

First of all, as long as an idea remains the product of the thought or alienation of an individual's thought, no matter how valuable or devalued, it cannot be considered ideology. Even a relatively broader social dissemination is not able to directly turn a complex of ideas into ideology. For this to take place, a precisely determined function is required, which Marx describes to accurately distinguish the material revolutions of the economic production conditions from the "legal, political, religious, artistic, or philosophical, in short, ideological forms in which men become conscious of this conflict and fight it out" (LUKÁCS, 2013, p. 464).

From the point of view of Lukács (2013), "ideology is above all a kind of ideal elaboration of reality that serves to make social and human praxis conscious and capable of action". According to the same author, ideology "[...] immediately and necessarily originates in the social hic et nunc of men who socially act in society". In this sense, "[...] every human reaction to the socioeconomic environment, under certain circumstances, may become ideology. This natural possibility of becoming ideology is ontologically based on the fact that its content [...]" - and not rarely its form as well - "preserves within itself the indelible marks of its genesis" (LUKÁCS, 2013, p. 465). For the author, the real antagonism of confronting ideologies "[... ] takes on the most disparate forms in the course of history and can manifest itself as an interpretation of traditions, religious convictions, scientific theories and methods, etc., which, however, always constitute, above all, means of struggle" (LUKÁCS, 2013, p. 465).

In this sense, formulations that constitute what we can call "false consciousness" do not always become ideology ${ }^{1}$. These formulations "[...] can convert themselves into ideology only after having become a theoretical or practical vehicle to tackle or solve social conflicts, whether these are of greater or lesser extent, determinant of the destinies of the world or episodic" (LUKÁCS, 2013, p. 467).

Thus, even a real truth can be an instrument to solve social conflicts and, consequently, become ideology. Hence Lukács (2013, p. 468) considers that the "concrete meaning of ideology [...] is broader than the strict concept of ideology. It only means - in a seemingly tautological way - that, regarding the social being, nothing whose birth is not decisively determined by this same social being can occur". In this sense, taking the structuring of daily life into account, Lukács $(2013$, p.470) says that it is in this space that what can be understood as ideology, in the broadest sense of the term, is most clearly shown, since "[.. .] the life of every man, and, consequently, all his achievements, be they practical, intellectual, artistic, etc., are ultimately determined by the social being in which said individual lives and acts".

Therefore, if ideologies serve for men, once these have become conscious, to set their minds on solving social conflicts, the existence of ideologies also presupposes their existence. In addition, if singular men are bearers of conflicts, this is due to the fact that they are also, ontologically, "[...] immediate bearers of all social activity [...]" (LUKÁCS, 2013, p. 471). 
In the immediacy of concrete life, says Lukács (2013, p. 471), conflicts present themselves as a clash of singular interests or as an opposition between these singular interests and the collective ones, or between the interests of different human groups. Thus, the human groups themselves form from singular individuals that have rather similar interests which, at the same time, are opposed to the interests of other social groups. In this sense, it is already possible to see, more generally, the emergence of ideologies, as, according to the author, these

[...] antagonisms can only be effectively addressed in society when members of a group manage to persuade themselves that their key interests coincide with the major interests of society as a whole and that each of those who advocate these interests are, therefore, simultaneously doing something useful for the entire society. Whether this is imposed by means of persuasion, with conspicuous or disguised violence, it results in important nuances, but this is not decisive to determine them as ideologies, nor is the question whether the content corresponds to social facts, to the tendencies of the time or is in contradiction with them, whether the conviction that guides an ideologically determined action in singular men and in their groups is sincere or hypocritical, etc. These views are of decisive importance for the actual socio-historical analysis of singular ideologies, but they are not a defining characteristic of ideology in general terms (LUKÁCS, 2013, p. 471-472).

Thus, the emergence of ideologies presupposes a certain social structure made up of different groups possessing antagonistic interests, and each acts to have their interests assimilated as if they were those of the entire society. According to Lukács (2013, p. 472), "[...] the emergence and dissemination of ideologies manifest themselves as a general trademark of class societies".

The same author warns, however, that this analysis in general terms is correct, but "[...] this determination can only become an engine of praxis when singular men experience these interests as their own and try to impose them in the context of crucially important relationships for them with other people" (LUKÁCS, 2013, p. 472).

In the capitalist mode of production, the production of wealth is expropriated from who produces it in order to ensure the accumulation of the class that owns the means of production. In view of the class struggles arising from this form of production organization, a legal teleology emerges that, albeit characterized as a system marked by the discrepancy between its representations and economic reality, plays the role of judicially regulating the social exchange among men.

In the process of social complexification, law eventually acquires relative autonomy, allowing it to provide "plausible" explanations for the existence of rules that are contradictory to each other and often only apparently seem to be disconnected from the hegemonic interests. This relative autonomy or detachment of law from the economic structure and social relations in which it originates blurs the processes of labor exploitation and the reification of men, that is, reification through the universalization of the mercantile form. And it is in the formal equality ensured by law that, in the capitalist mode of production, this universalization of the mercantile form becomes viable, based on the 'principles of private property and freedom of contract whereby individual bearers of goods willingly establish exchange relations.

The law complex disguises the essence of phenomena and, in this sense, due to its social function, constitutes an ideology whose goal is to achieve the submission of men to the economic structure and the cover-up of class struggles, as Lukács puts it (2013). Therefore, this teleological position plays the role of judicially regulating social conflicts.

In class society, as interests clash against one another, there is a need to regulate the social relations by law - unlike the nature of those regulations that spontaneously emerged from social practices (by tradition or by custom). This legal regulation has the main function of laying down rules that address a key issue: the way the surplus produced by labor activity is utilized. Thus, the form of organization of capitalist production, based on the private property of the means and results of work by a class, cannot do without mechanisms aimed at subjecting the non-owners to its logic. As the strategies to produce surplus by labor in the form of commodity develop, new forms of regulating the access to these also advance by means of legal guarantees. 
Although the legal structures are relatively autonomous and there is no mechanical relationship between the multiple social complexes and the economic complex, this is seen by Lukács (2013) as a mediation to understand the dynamics of the social complexes that constitute the social totality. He states that it would be wrong to infer that these complexes consist of mere partialities determined by the original complex of economy (labor) as if they were simply derived, inferred from this complex. Each of these responds in a peculiar way "[...] to the impulses that the general movement of the social being triggers in economy [...] (LUKÁCS, 2013, p. 270-272).

Considering these Lukacsian reflections, we can see why law appears to us as a given aspect of reality, as an ahistoric element. The immediate understanding that is limited to the form of appearance of this phenomenon is shaped by the ideological load of the legal complex itself. The overcoming of this phenomenal perspective of law can only take place when we manage to determine the connections between the dimensions of social reality in its totality, in which the legal phenomenon itself is included. Grasping this complex totality is imperative to understand how, on the socio-historic ground, according to Lukács (2013, p. 277), there is a "[...] self-preservation of an essence [...]" that undergoes transformation "[...] in the midst of constant change". According to Lukacs (2013, p. 492, emphasis added by the author), in "[...] social reality, the boundaries between essence and phenomenon often become fluid [...]" and, for this reason, "[...] the actual differences can only be verified with some accuracy a posteriori by means of conceptual, scientific analyses".

For Lukács (2013), certain relations of production condition-specific forms of law and the interrelationship between these complexes " $[. .$.$] is so strong at the immediacy of the social being that acting$ people have to imbue them with a unitary objectivity for the presupposition or object of their teleologicalpractical positings". Anyway, this conjunction does not negate the fact that these are distinct complexes of the social being, relatively autonomous from one another, nor does it "[...] prevent the relations of production, propelled by the development of the productive forces, from changing independently of the legal system and, thus, necessarily imposing on it a total or partial codification or at least the corresponding reinterpretations "(LUKÁCS, 2013, p. 492-493).

In Lukács' view, there is always a real field of activity where the teleological positings appear as possibilities exclusively for this field, suppressing, thus, any predetermination. This makes "[...] the need of the essence forcibly take on the form of possibility for the praxis of singular men" (LUKÁCS, 2013, p. 494).

From a Marxian perspective, according to Lukács (2013), "[...] the conflicts brought about by the contradictory development of the economy (the development of the productive forces as transformation, as an explosion of the relations of production) are confronted and solved with the means of ideology [...]". In addition, it should be noted that "[...] the economic essence, operating independently of any human will as regards the totality of society, that is, ultimately, mankind, produces only objective possibilities of real progress" (LUKÁCS, 2013, p. 495).

Also according to Lukács (2013, p. 495), such possibilities are, at the same time, "[...] irresistibly necessary $[\ldots]$ " and "[...] necessarily progressive $[\ldots]$ " towards an "[...] increasingly more social form of the social being, towards a self-being increasingly less falsified ontologically; however, as far as the destiny of mankind is concerned, only objective possibilities remain (LUKÁCS, 2013, p. 495-496).

The Hungarian philosopher asserts that in this process a crucial contradiction arises for the development of the social being which "[...] determines the relation between base and ideology both in the daily life of slow reproduction and successive unfolding of a formation and in the major crises that take place in the transition from one formation to another" (LUKÁCS, 2013, p. 496).

Furthermore, understanding the legal complex and how law is grasped by social workers in the context of Brazilian reality requires a theoretical and political effort capable of taking hold of this understanding and of how professional agents also comprehend this reality, whose structure and dynamics are conditioned by the forms of economic and political domination of the monopolist bourgeoisie attentive to the formulation of strategies that ensure the valorization of value and ameliorate the negative impacts of the falling rates of profit. The actions that allow the conflicts arising from class struggle to be controlled and the tensions caused by the organizational processes of workers to be neutralized are central to these strategies. It is 
also in this context, in the dispute for the right to enjoy the wealth socially produced, that the activity of the social worker is situated.

\section{Social work and the struggle for rights}

Looking at Marx's positions in "German Ideology", Lukács (2013, p. 496) mentions that, in the development process of the social being, the social division of labor actually occurred at a time when material work and spiritual work were also set aside. This does not mean that spiritual work - as in the moment of labor division - is equivalent to ideology according to Marx and Lukács. However, there is no denying that these two elements largely overlap. This is because, according to Lukács (2013, p. 496):

[...] the result of all spiritual work can, in certain social situations, revert to ideology, even the social division of labor produces uninterrupted situations in which this reversal becomes necessary and permanent. In these cases, this comes to light in the very division of labor. If such a permanent social need to regulate the problems that arise in the reproduction of life eventually becomes a need that is reproduced simultaneously to the reproduction process, this type of activity becomes socially necessary, which is expressed in the fact that singular individuals or entire groups can make it a specific occupation from which they live.

In view of the developments and complexities that are constituted in the construction process of the social being, some activities seem to have little or no relation to production, even if they are indispensable for it to take place. Then Lukács (2013) stresses the legal regulations. According to him, this also "[...] has nothing to do with material production itself; however, from a certain stage, it could no longer occur without friction, without a legal regulation of sharing, exchange, etc.", which, in order to be performed, require individuals who end up making a living from this praxis. Thus, these men ensure the reproduction of their lives, on an individual and generic basis, without having to directly participate, for this purpose, in "[...] the immediate material production of the essence". For this to occur, according to the author, the social being should reach a certain level of development in which it is possible to ensure the reproduction of that stratum of men, "[...] which would not be possible without a reduction in the time of socially necessary work for reproduction in immediate production". Only when society, by demand of its own development, gives rise to legal experts who live from activities carried out in the sphere of reproduction, is it possible to understand law as a specific ideology (LUKÁCS, 2013, p. 497).

In our view, in this context, by making the Lukacsian statement about the emergence and function of law and legal structures with their experts more flexible, we can also situate social work. This is because the activity of social workers, historically, from different theoretical hues, has always been involved with a set of rights that characterize the civilizational standard reached, although in Brazilian reality this standard has always been very low and marked more by discontinuity than by a tendency towards its progressive consolidation.

In any case, what should be noted is that the complexification of the social being imposes an increasingly greater differentiation in the social division of labor, and, in order to respond to the conflicts that arise in the process of permanent constitution of that being, "[... ] interconnected systems are elaborated in a rather rational way $[. .$.$] ", which have the function of coping with and seeking resolutions to these conflicts," [. .$.$] in$ accordance with the interests of society “(LUKÁCS, 2013, p. 497).

However, we should bear in mind that, according to Lukács (2013, p. 497),

[...] when class stratification in society becomes reality, these interests tendentiously coincide with those of the ruling class at that time. And the expression "tendentiously" takes us exactly to the core of the class struggle problems, since its content is, in a very large number of cases, a decision about how, according to some principles, a general way of solving conflicts will be constituted (think of the struggles for the right to strike). 
Thus, if we admit that law is a response to solve problems and conflicts within society, and if these responses are "tendentiously" formulated in line with the interests of the ruling class, the evaluation of Lukács (2013, p. 501) for whom jurists are precisely those who pose "[...] greater resistance against an ontologically correct understanding of ideologies [...]" becomes clearer. It should be noted again that there is no determinism in the reflections brought up by the author. When he asserts that law is linked to the interest of the ruling class, he describes this link as a "tendency". Therefore, he shows a field of possibilities that may lead to social processes that escape the control of the ruling classes. As we know, this is also valid for social workers, as the category expresses its opposition to the hegemonic interests in its ethico-political project, whose values and principles clash against the perspective of maintaining a class society. Social work is, therefore, also a field of disputes whose social direction is set by the correlations of forces that clash within the profession, but which also portray the struggles and antagonisms present in Brazilian society ${ }^{2}$. Thus, what is understood as "rights", the scope and limits of these "rights" in the dynamics of confronting classes, is directly related to the societal projects being disputed and which impact the formulation of different professional projects.

Relying on the discussions by Engels, Lukács (2013) notes that law is an internally coherent system because, in other words, it does not boycott itself by disclosing its contradictions. However, its structuring and "coherence" are "[...] built so as to become appropriate to tackle and solve conflicts as regards the existing society in each concrete case, as regards the existing proportions of class power in each case, at the level of the highest possible universality in each case"(LUKÁCS, 2013, p. 498). By virtue of this, we can say that law tends to progressively bring about unreliable mirrorings of the economic relations, and, nevertheless, such false mirrorings may be appropriate "[...] to perform well-defined social functions" (LUKÁCS, 2013, p. 498).

In discussing these "distortions" related to social reality resulting from legal positings, the author shows that, in the field of law, there is the predominance of a formal logic that denies the existence of contradictions, which leads jurists to "[ ...] build false knowledge of the structure of the social being that results therefrom" (LUKÁCS, 2013, p. 499). If our understanding of the author's teachings is correct, we can say that the connection of law with social objectivity is of little importance, as what should prevail and determine legal responses are the hegemonic interests, accordingly linked to the interests of the ruling class. It is precisely in this direction that these responses should propose well-defined forms of conflict regulation in order to solve them (LUKÁCS, 2013, p. 499).

These reflections of the author allow us to think about the very activity of social workers, given that, in their daily action, legal norms and rules translated into laws in a broad sense are usually taken as the basis for decisions regarding the demands that are placed in different socio-occupational contexts. Social workers often embrace the assumption that legal and institutional norms are suitable to users' needs and are also correct parameters to "measure" the access to socially established rights. As a result, a conviction and a conservative consensus are built on what is a right (what is assured) and what is not a right (not provided for in regulations, or, even when provided for, it does not cover certain subjects that have been excluded by eligibility criteria under the guise of "fairness"), while, at the same time, class antagonisms and determinations of reality are abstracted. The myth of "impartiality", as it is in the legal area, imposes itself in such a way that the professional activity must be guided by irrefutable technical knowledge, even if such technicality is functional to the interests of the hegemonic classes and has little or no connection with the ideals of justice - even bourgeois - and with the social needs of users.

As we already mentioned, for Lukács $(2013$, p. 500) "[...] the differentiation of the social division of labor created professional jurists simultaneously to the doctrine of law". And it is only by virtue of this, according to the author, that "[...] the specific type of being of law is consummated as ideology, while many important ideological forms, such as custom, convention, etc. emerge spontaneously".

The ideological divergences between law and economic reality arising from legal elaborations are progressively accentuated as these experts (professional jurists) intend "[...] to confer the greatest possible weight on their activity in the total complex" (LUKÁCS, 2013, p. 501). Making use of Engels' explanations, Lukács (2013, p. 501) considers that, precisely because legal activity “[...] goes back 'again' to the economic 
base, and can modify it within certain limits, the specifically ideological point of view experiences uninterrupted intensifications [...]", so that "[...] the content and the form of law often appear petrified in a purely fetishistic way as forces of humanity". And, in this sense, the phenomenal form is taken as if it were the essence and hence "[...] the real struggle of real men for their existence takes a back seat as an unworthy underworld of existence" (LUKÁCS, 2013, p. 501).

According to Lukács (2013, p. 501):

The real nature of law can only come to light, therefore, when one understands this glorifying deformation as what it truly is, namely, an ideologization of ideology, which necessarily emerges when the social division of labor assigns its maintenance to a stratum of experts.

Ultimately, however, it must be understood that law, in order to become an effective instrument for conflict resolution from the perspective of the interests of the hegemonic class, must be presented as universal and cannot be, of course, a means of authentic reproduction of reality. From the point of view of ideology, it is important to know whether this specific being can perform the function of regulating life from a social and economic perspective in a way that responds to the conflicts arising in the development process of the social being. These responses need to be universalizing so as to be effective and valid for everyone indistinctly. And by virtue of this professed universality of its responses, it conceals the real inequalities of real men in daily life.

If this is valid for law as a derived social complex, as an ideological system that is formed through those regulatory functions of the social relations and the responses to conflicts, it is also valid for other complexes linked to it to a greater or lesser extent, as is the case of social work. The work of the social worker, in the context of total social work, is closely connected with law and, although it is not one of its internal elements, it engages in reciprocal relationships with law that eventually materialize the teleologies that circumscribe these two fields. As with law, social work presents itself as an important mediation in processes of resolution of social conflicts that manifest themselves in different forms, but which are rooted in the dynamic dialectics of the development of the social being, involving essence and phenomenon.

Social work certainly does not carry a homogeneous social image, but it is possible to say that it is recognized for its adamant defense of a significant set of workers' rights. The profession has historically been involved in the struggle for public health, for the formulation and expansion of the public policy of social work, for access to justice, for housing, for education, for public transportation, for the democratization of decisions about the contents and design of different social policies with a view to strengthening social control, etc., turning out to be a profession that is built on the very processes of these struggles. None of this should be neglected. However, the key question is whether, in the professional activity of social workers in different work settings, these struggles have been associated with the broader struggles of the working class. And, to extend the scope of analysis, we should ask ourselves: have social workers been able to articulate these and other partial struggles (through the rational use of natural resources, for gender equality, against LGBTphobia, against racism, etc.), standing up to the structures and dynamics of the current social order?

In this sense, the working hypothesis that we take as reference here is the idea that social workers have based their professional intervention much more on legal norms (federal constitution, laws, decrees, resolutions, institutional norms, etc.) than on social theories that have the potential to support the ethico-political project advocated by the category. In other words, social workers have taken legal norms as the basis for their practice in detriment of what actually is the basis for their professional work. This perspective neglects the Marxian warning that "law is the official recognition of the fact" (MARX, 1985), that is, it is the legal form formulated by the State to regulate the reality in which the social relations take place. The fact that the State is bourgeois and that it ultimately stands up for the interests of the economically and politically ruling class is abstracted from the teleological processes developed in professional work. We believe that this uncritical attitude towards reality accounts for most of the dilemmas experienced by the profession, but it encourages us to revert this situation to find 
alternatives to confront barbarism, an issue properly translated in the words used by José Paulo Netto (2015, p. 242):

[...] the professional ethico-political project of Brazilian social work has no guarantee at all. It is a project that, converted into a theoretical-practical process in these socalled times of uncertainty, condenses around its values a consensus that bets on some convictions and a few certainties. But these are completely necessary, since it is in times like these that the effort to elude perplexities and to find alternatives converts into a strategy against barbarism.

Without addressing the controversies over whether or not there is a crisis in the hegemonic project of social work, despite the resistances that have marked the present time, we have faced an important advance of the conservative thought into all dimensions of social life, and this has direct repercussions within the profession. This advance has materialized into formulations in the theoretical, technical and academic production of social work that often question or assert the inability of critical social theory, most notably that of a Marxian and Marxist nature, to "respond" to professional demands. The very ontological knowledge of reality, from a perspective of totality, is negated in arguments of this kind.

Inasmuch as positive law is the element par excellence that guides professional work, it should be noted that this complex indeed provides, as Lukács (2013) teaches us, responses to the hegemonic interests, although, on the other hand, these answers may be pervaded by the contradictions of the bourgeois order and simultaneously allow certain needs of workers to be fulfilled.

What we intend to emphasize here is that, if social workers reinforce the tendency to make the legal system available the privileged "foundation" of their professional work - even if this has tactical importance in the struggle for the defense of social rights - they will be restrained in the context of the struggle for political emancipation, which, although necessary, is insufficient to implement an emancipatory societal project.

In Critique of Hegel's Philosophy of Right, Marx (2010, p. 151, emphasis added by the author) states that:

\footnotetext{
The weapon of criticism cannot, of course, replace the criticism of the weapon, material force must be overthrown by material force, but theory also becomes a material force as soon as it has gripped the masses. Theory is capable of gripping the masses as soon as it demonstrates ad hominem and it demonstrates ad hominem as soon as it becomes radical. To be radical is to grip the root of the matter. But, for man, the root is man himself.
}

And, as we try to demonstrate in light of Lukacsian thinking, law tends to be an instrument of class domination, consisting of an ideological mediation to solve conflicts arising in the process of development of the social being, with a view to the reproduction of the capitalist social form. In this sense, as we reflect on the challenges imposed upon social work by the reality of Brazilian capitalism today - marked by a continued and intense offensive against social rights - we have the ultimate proof that the achievements that make up this set of rights are not perennial. With each cycle of capitalist crisis, these achievements tend to be suppressed or reduced in order to create counter-tendencies to the decline in the capitalists' rates of profit. In these moments, even essential principles of bourgeois law itself are not supported - such as the principle of prohibition of social retrogression ${ }^{3}$ - and, as Marx $(2013,309)$ says, in the context of a class society where formal equality prevails and real inequalities are abstracted, in the confrontation between equal rights, "who decides is the force".

Marx himself warned in writings prior to his most important work (The Capital), when facing what he called "material issues", about the illusions created from the ideals of abstract universality of bourgeois law. This occurs when he positions himself in his articles in the Rhenish Newspaper (in 1842) in favor of the poor population in the face of the prohibition of a practice consolidated by custom: the collection of wood from forests ${ }^{4}$. This right that had emerged from the poor's customs clashed against the legal right of rich owners once a law came into effect punishing those who "stole" wood from private properties. This law revealed, 
according to Marx (2017), how fragile the idea of the universality of the state (and bourgeois law itself) was, insofar as it turned the bourgeois interest into general interest, disregarding the needs and habits of the poor, who, in essence, revealed the "instinctive sense of right". Thus the abstract universality of bourgeois law is presented as such by the permanence and prevalence of the private interests of the ruling classes over the interests of the poor classes, almost always treated as privileges to be wiped out. From a perspective of the social worker's work, it is not uncommon that the defense of the established norm or the defense of the positivation of rights implies denying the very needs of workers, inasmuch as, within class society, the contents of rights are limited by the opposition to the interests of capital.

The realization of the constraints on the social worker's professional activity within class society and its relationship with bourgeois law in the attempt to extend the access of social service users to the wealth produced cannot allow any determinism to prevail. This warning challenges us to think about the necessary connection between social workers' advocacy for the creation, defense, and extension of rights and the struggle for human emancipation. The point is that the struggle for rights is not always an anti-capitalist struggle, which leads social workers to become hostages to the illusions mentioned by Marx. In this sense, they end up contributing to the reproduction of capitalist social relations, inasmuch as their daily actions reassure processes that result in the formal and real submission of workers to capital. In our view, this is related to the fact that, in responding to the demands of the labor market without subjecting them to a critique based on substantive rationality (Guerrero, 2014), social workers have trailed paths that reify the technique, bureaucratic procedures and institutional flows - striving to appear and to be competent from the perspective of the labor market - to the detriment of developing the ability to unveil the historical processuality of these demands in order to fulfill the real needs of workers. This attitude has gradually removed them from the critical field and from the professional projects that have been built since the last decades of the 20th century. The reversal of this trend can only occur through the same mechanism that gave rise to the processes that aligned the Brazilian social work with critical perspectives: the political struggle of the category connected with the struggle of the workers' movements and the grasping of reality through the method developed by Marx, as this is the method capable of laying bare the historical and social processuality.

\section{Some Final Considerations}

Yes! "Not a single right less". However, our political-academic organizations and our action programs in workplaces and training places need to be guided by critical social theory assumptions capable of allowing us to overcome shallow explanations that capture only the appearance of social phenomena. It is necessary to contribute for the new to be truly new and not a reinvention of the old that perpetuates the social structures that generate the illusions that still dwell in our hearts and minds regarding the possibilities of the profession in the context of the struggles for rights in an order ruled by the capital, especially in the context of Brazilian society, where the ultraconservative political forces have reinvigorated the hate speech against the poor and other minorities. For social work to advance its ethical and political commitment to the construction of a society without class exploitation and without any forms of domination, it is necessary to give up on the abstract narratives about rights (and their principles) that conceal class antagonisms and absorb only partially the actual needs of workers. In addition, in the horizon of struggle for political emancipation, these rights are always reduced or suppressed during the worsening of capitalist crises. This indicates that the struggle for rights is always necessary, but the beacon that guides the work of a social worker is the human emancipation project. To follow this path, more than knowing the legal norms that regulate rights - which are never perennial - professionals must grasp the social reality in which the social processes that give rise to such laws come into being with the purpose to control class conflicts and to reproduce the social relations proper to the capitalist mode of production. The appropriation of this dynamics is essential for the profession to formulate answers to the demands placed on it that are consistent with the rejection of a social order that subjugates the interests of workers to the interests of capital. 


\section{References}

BENSAÏD, Daniel. Os despossuídos: Karl Marx, os ladrões de madeira e o direito dos pobres. In: MARX, Karl. Os despossuídos. São Paulo: Boitempo, 2017.

FONTES, Virgínia. O Brasil e o capital-imperialismo: teoria e história. Rio de Janeiro: EPSJV, 2010.

GUERRA, Yolanda. A instrumentalidade do serviço social. 10. ed. São Paulo: Cortez, 2014.

LUKÁCS, György. Para uma ontologia do ser social II. São Paulo: Boitempo, 2013.

MARX, Karl. A miséria da filosofia. São Paulo: Global, 1985.

MARX, Karl. Crítica da filosofia do direito de Hegel. São Paulo: Boitempo, 2010.

MARX, Karl. O capital: crítica da economia política. São Paulo: Boitempo, 2013. (O Processo de Reprodução do Capital, Livro 1).

MARX, Karl. Os despossuídos: debates sobre a lei referente ao furto de madeira. São Paulo: Boitempo, 2017.

NETTO, José Paulo. O projeto ético-político profissional do serviço social brasileiro. Intervenção Social, Lisboa, n. 42/45, p. 229-242, 2015.

SARLET, Ingo Wolfgang. Notas sobre a assim designada proibição de retrocesso social no constitucionalismo latino-americano. Revista do Tribunal Superior do Trabalho, Brasília, v. 75, n. 3, p. 116-149, jul./set. 2009.

\section{Notes}

${ }^{1}$ In another segment, Lukács (2013, p. 480) asserts: "it is certainly correct to say that the overwhelming majority of ideologies are based on assumptions that cannot withstand a strictly gnosiological critique, especially when this takes a vast time period as the starting point. In this case, however, this is a critique of false consciousness; nevertheless, in the first place, there are many achievements of false consciousness that have never converted into ideologies, and secondly, what has converted into ideology is by no means necessarily and simply identical with false consciousness. For this reason, it is only possible to understand what really is ideology through its social action, through its social functions".

2 For this discussion, we recommend the book by Virgínia Fontes titled "O Brasil e o capital-imperialismo: teoria e história", published by EPSJV/Fiocruz and the UFRJ Publishing House in 2010.

${ }^{3}$ This legal principle is related to the idea of irreversibility of fundamental rights. According to Sarlet $(2009$, p. 123), in its broadest sense, this principle means "[...] protection of rights against restrictive measures, for all fundamental rights". The same jurist states: "[...] if the constitutionally appropriate and responsible management of the principle of prohibition of retrocession (which definitely does not lend itself to shielding unjustifiable privileges, simply because these were, in a given context, secured to certain groups of people) is certainly not the only way to protect the fundamental social rights, there is no doubt either that this is a major juridical and constitutional dogmatic achievement [...] to ensure, especially at the level of negative effectiveness, the protection of social rights against their suppression and erosion by the powers that be, most notably in an environment characterized by accentuated social and economic instability, as is also the case of the Latin American setting (SARLET, 2009, p. 149).

${ }^{4}$ In the presentation of the book Les Dépossédés (2017), Daniel Bensaïd contextualizes the practice of collecting wood and other forest products that were used for the manufacture of brooms, repair of household utensils, manufacture of roofing slats, building of stairs, as material for heating (firewood), etc. According to the author, Marx shows that the increase in the "theft" of wood unveiled the poverty of the rural population. The creation of a law that punished the customary practice of collecting these materials was an answer to the interests of owners in view of the "[...] fact that the integration of wood into the circuit of commercial value creation makes its use value and its exchange value inseparable. The challenge of the new legislation is to assert the right to property, rigorously distinguishing the entitlement to property from the entitlement to necessity, exchange economy from subsistence economy “(BENSAïD, 2017, p. 16-17).

Received: 2019/04/02.

Approved: 2019/09/04

Published: 2019/10/10

\section{Correspondence to:}

Jaime Hillesheim

Federal University of Santa Catarina

Campus Rector João David Ferreira Lima - Trindade

88040-900, Florianópolis, SC, Brazil

Author:

JAIME HILLESHEIM

Department of Social Work by Federal University of Santa Catarina, Florianópolis, SC, Brazil.

CV: http://lattes.cnpq.br/5960974102571301

Orcid: https://orcid.org/0000-0002-2798-6418

E-mail: Jaime.h@ufsc.br 